\title{
CONF-820948--3
}

UCRL- 87528

PREPRINT

THE TECHNOLOGY DEVELOPMENT FACILITY (TDF)

J. พ. Doggett

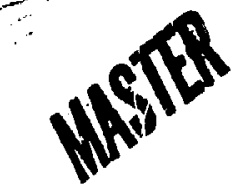

This paper was prepared for submittal to the Iwelfth Symposium on Fusion Technology

Julich, Federal Republic of Germany September 13-17, 1982

4

September 3, 1982

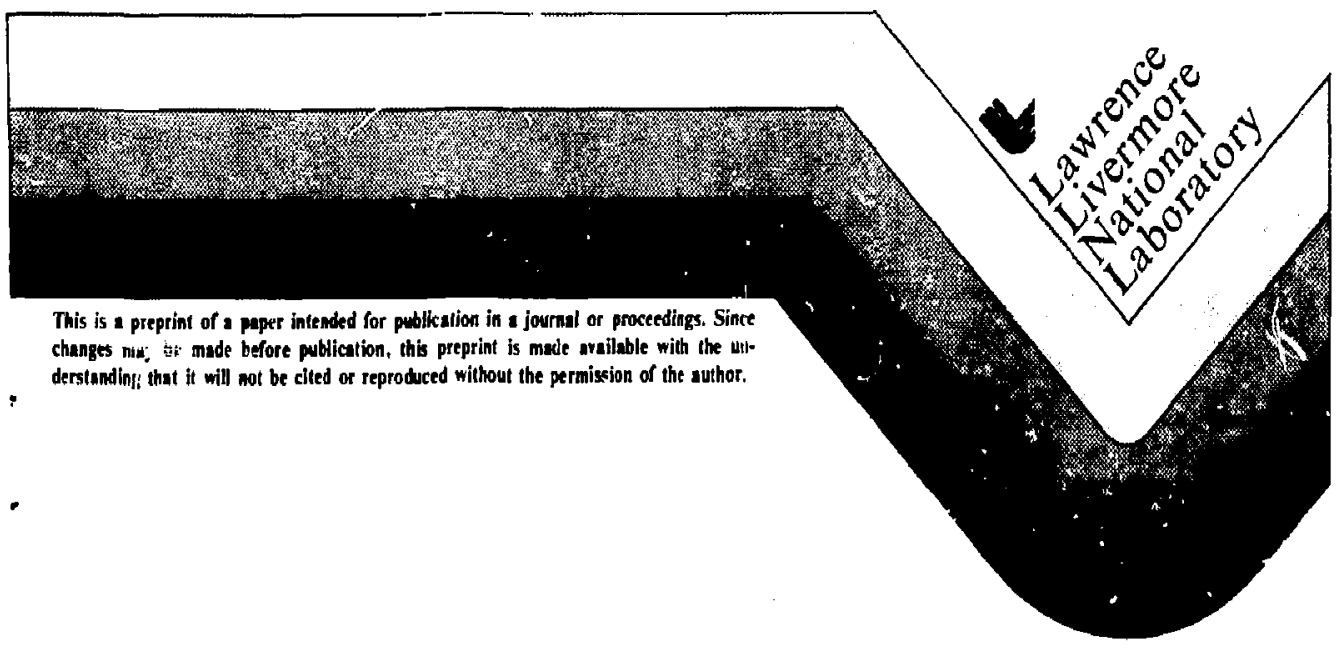

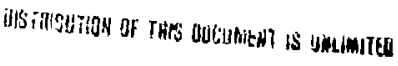


THE TECHNOLOGY DEVELOPMENT FACILITY (TDF)

\author{
J. N. Doggett \\ Lawrence Livermore National Laboratory, University of California \\ UCRL- -87528 \\ Livermore, CA 94550 \\ DER2 022069
}

\title{
ABSTRACT
}

We have been studying small, driven, magnetic-rnirror-based fusion reactors for the Technology Development Facility (TDF), that will test fusion reactor materials, components, and subsystems. Magnetic mirror systems are particularly interesting for this application because of their inherent steady-state operation, potentially high neutron wall loading, and relatively small size.

Our design is a tandem mirror device first described by Fowler and Logan $/ 1 /$, based on the physics of the TMX experiments /2/at Lawrence Livernore National Laboratory (LLNL). The device produces $20 \mathrm{MW}$ of fusion power with a first-wall, uncollided $14 \mathrm{MeV}$ neutron flux of $1.4 \mathrm{MW} / \mathrm{m}^{2}$ on an area of approximately $8 \mathrm{~m}^{2}$, while consuning approximately $250 \mathrm{MW}$ of electrical power. The work was done by a combined industrial-laboratory-university group. *

\section{PHYSICS DE5CRIPTION}

Calculations indicate that the TOF, consisting of a tendem mirror machine about the size of the TMX, could provide fusion nuclear engineering data. With higi-density operation, based an physics already demonstrated in the TMX, this machine would produce $15 \mathrm{MW}$ of DT neutrons in steady-state form from a plesma column $0.10 \mathrm{~m}$ in radius and $8 \mathrm{~m}$ in length.

To produce copious neutrons in a sinall device, we use the fact that iven small mirror machines have confined dense plasmas at high ion temperatures. Because of the small volume, neutral beans can maintain these plasmas in steady-state forr with modest demands an the plasma confinement time. This was the principle behind the earlier Fusion Engineering Research Facility (FERF) /3/, based on a yin-yang mirror geometry. The tandem mirror version has the advantages of somewhat simpler construction as well as a configuration in the mainstrearn of tandem-mirror reactor development.

For the TDF base case, $65 \mathrm{MW}$ of $80-\mathrm{keV}$ neutral-beam power (half deuterium, half tritium) is injected into the center cell to sustain a mirror-confined ion density of $6 \times 10^{14} \mathrm{~cm}^{-3}$ ut an average energy of $37 \mathrm{keV}$. In this mode of tandem-mirror operation, known as the Kelley mode, the enc cells serve three fumations: provide MHD stability, eliminate axial ambipolar electric fields in the center cell, and confine low-energy ions that fill in the loss cone in the center cel!. Loss-cone instability in the end cells themselves is "stream-stabilized" by the autflow of lowenergy ions from the center cell, which are regulated by the input of gas to the centes cell. A brief set of physics parameters is shown numerically in table $l$ and graphically in fig. 1.

* The principal participants are LLNL, TRW, Fusion Engineering Design Center of Oak Ridge National Laboratory, General Dynamics/Convair Division, University of Wisconsin, and Science Applications, Inc. 
Table 1. TOF Physics Parameters.

\begin{tabular}{|c|c|}
\hline $\begin{array}{l}\text { Central cell } \\
\text { Plasma length (m) } \\
\text { Plasma radius (m) } \\
\text { Solentid (T) } \\
\text { Peak beta } \\
\text { Hot-ion average energy (keV) } \\
\text { Hot-ion density (cm-3) } \\
\text { Beam voltage }(\mathrm{kV}) \\
\text { Incident beam power (MW) } \\
\text { Trapped beam current }(\mathrm{A}) \text { atomic } \\
\text { Injection angle (degrees) } \\
\text { Pellet gas feed (A) atomic } \\
\text { Fusion power }(\mathrm{MW}) \\
\text { Neutron wall flux }\left(\mathrm{MW} / \mathrm{m}^{2}\right) \text { at } R=0.25 \mathrm{~m}\end{array}$ & $\begin{array}{l}8.0 \\
0.1 \\
4.5 \\
0.4 \\
37.0 \\
6 \times 10^{14} \\
80.0 \\
64.8(1080 \mathrm{~A} / 60 \mathrm{keV}) \\
853.0 \\
65.0 \\
2800.0 \\
220.0 \\
1.4\end{array}$ \\
\hline $\begin{array}{l}\text { Choke--Transition } \\
\text { Pmax choke }(T) \\
\text { Plasma length }(\mathrm{m}) \\
\text { Plasma dengity }\left(\mathrm{cm}^{-3}\right) \\
\text { Field at midplane }(T) \\
\text { Pumping NBI }\end{array}$ & $\begin{array}{l}15.0 \\
4.75 \\
<3 \times 10^{-12} \\
1.0 \\
80 \mathrm{kV},(59.2 \mathrm{~A} / 60 \mathrm{keV}) 3.6 \mathrm{MW}\end{array}$ \\
\hline $\begin{array}{l}\text { Anchors } \\
\text { Plasma length }(\mathrm{m}) \\
\text { Plasma density }\left(\mathrm{cm}^{-3}\right) \\
\text { Field at mirror }(T) \\
\text { Field at midplane }(\mathrm{T}) \\
\text { Sloshing neutral beams } \\
\text { ECRH } \\
\text { Pumping NBI }\end{array}$ & $\begin{array}{l}3.3 \\
25 \times 10^{1} 2 \\
3.0 \\
1.0 \\
80 \mathrm{kV},(4.2 \mathrm{~A} / 60 \mathrm{keV}) 0.25 \mathrm{~W} \\
500 \mathrm{~kW}: 35 \mathrm{GHz} / 667 \mathrm{~kW}: 00 \mathrm{GHz} \\
80 \mathrm{kV},(2.9 \mathrm{~A} / 60 \mathrm{keV}) 0.17 i \mathrm{MW}\end{array}$ \\
\hline
\end{tabular}

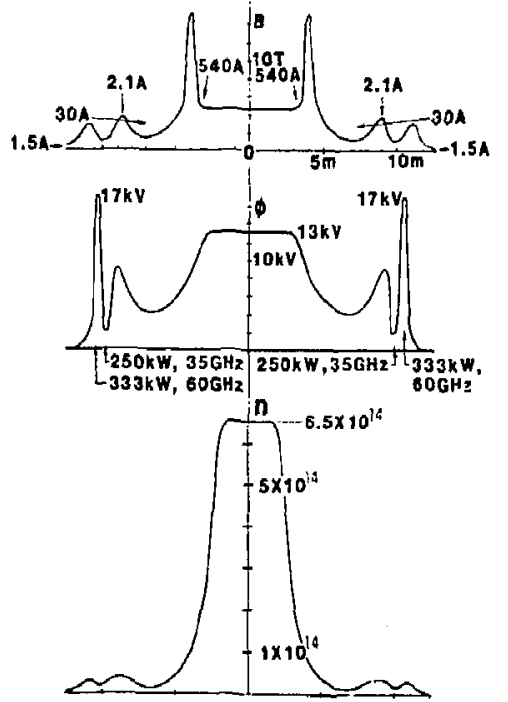

Fig. 1. Magnetic field, plesma potential, and density profiles in TDF.

\section{ENGINEERING}

The TDF resctor subsystems were deliberately designed to existing or near-term technology. Table II cantains the design parameters; fig. 2 shows the overall system desiqn. At the center of the machine is the central-cell region where virtually all of the neutrons are produced. Here the centerline magnetic field of $4.5 \mathrm{~T}$ is produced by three $\mathrm{Nb}$-Ti superconducting magnets spaced to allow the insertion of test modules up to $I m$ in axial dimension. The ends of the central cell provide access for the central-cell beams that drive the fusion reactions. The main design considerations in this area are shieiding for the solenoid magnets in the area adjacent to the beam ducts and the desire to keep the 15-T resistive choke coil as close to the solenoids for field reinforcement. The choke coil presents a novel design problem for fusion reactors because it must withstand a high radiation load and has $a$ high internal heat losd and high magnetic gtresses. 
Tahle I. TCF Engineering Parameters

\begin{tabular}{|c|c|c|c|}
\hline \multirow{3}{*}{$\begin{array}{l}\text { Dyarall machine } \\
\text { Full-power-run length (hr) } \\
\text { Availability ( } \mathrm{x} \text { life average) } \\
\text { Design life (full power yrs) }\end{array}$} & & Vacuum & \\
\hline & $\begin{array}{r}>100 \\
30 \\
5.4\end{array}$ & $\begin{array}{l}\text { Base pressure (torr) } \\
\text { Total pump speed }(\ell / s)\end{array}$ & $\begin{array}{r}5 \times 10^{-6} \\
1.3 \times 10^{8}\end{array}$ \\
\hline & & Neutral beams & \\
\hline Test zone & & Continuous made & \\
\hline First wall radiug (m) & 0.25 & Maximum energy (kev) & 80 \\
\hline Neutron wall load $\left(\mathrm{MW} / \mathrm{m}^{2}\right)$ & 1.4 & Power & \\
\hline Area available $\left(\mathrm{m}^{2}\right)$ & 28 & Central cell (MW) & 52 \\
\hline Heat load $\left(W / \mathrm{cm}^{2}\right)$ & 50 & Pumping (MW) & 3.8 \\
\hline Fusion power (MW) & 20 & Sloshing (MW) & 0.25 \\
\hline Tritium & & & \\
\hline Consumption rate $(\mathrm{gm} / \mathrm{hr})$ & 0.1 & RF & \\
\hline Inventory $(\mathrm{kg})$ & 20.3 & ECRH-type & \\
\hline Magnets & & $\begin{array}{l}\text { Frequency }(\mathrm{GHz}) \\
\text { Power (MW) }\end{array}$ & $\begin{array}{l}35 / 60 \\
1.2\end{array}$ \\
\hline Superconducting Nb-Ti & & & \\
\hline Peak conductor field (T) & 8 & Pellet injectors & \\
\hline Peak center field $(T)$ & 4.5 & Velocity $(\mathrm{m} / \mathrm{s})$ & 1500 \\
\hline Pesistive Cu alloy & & Peliet rute $(/ \mathrm{s})$ & 500 \\
\hline Peak center field ( $T$ ) & 15 & & \\
\hline
\end{tabular}

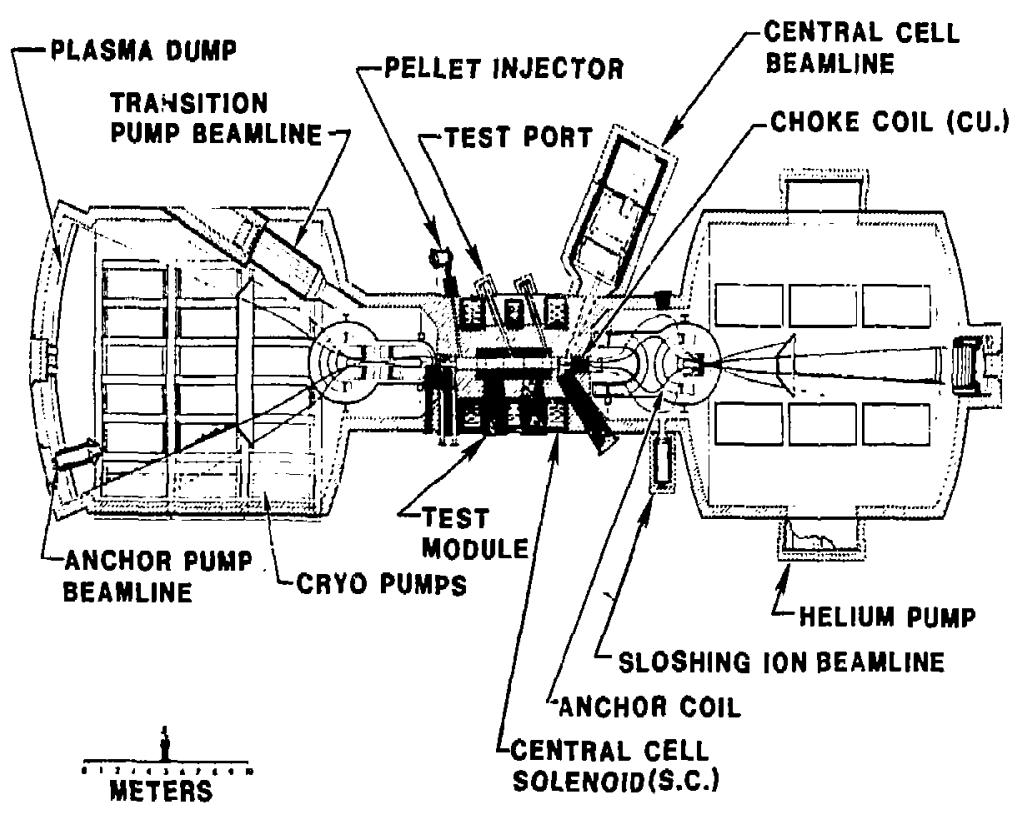

Fig. 2. TDF cross section (some components are shown rotated out of plane for clarity).

Beyond the central cell are the transition and anchor regions, which stabilize the central-cell plasma. The fusion power in this region is small, and only minimal shielding is required. The magnets are C-shaped with an $\mathrm{Nb}-\mathrm{Ti}$ conductor and are housed in an independent vacuum vessel. Three neutral beam systems deliver particles to this area: two are pump beams that enter at shallow angles; the other provides sloshing ions normal to the axis. The relatively complex magnet geometry coupled with rigorous beam geometrical requirements control the design in this ares. 


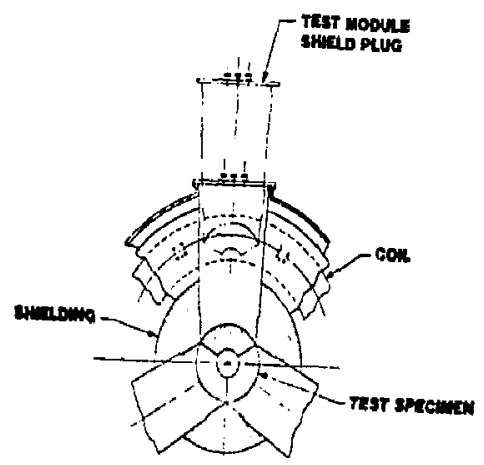

Fig. 3. TDF test module replacement detail.
The end cell is the outbosrd part of the system, and its principal functions are: (1) to provide the primary vacuum pumping, (2) to provide a dump for the plasma-feakage power, anc (3) to house the plasma startup system. vacuum pumping is provided by cycling cryopumps located above and below the plasma leakage fan. There is sufficient redundant pumping capacity that some of the pumps are always off-line being degassed. The internal tritium inventory can be controlled by the amount of excess capat ity specified. The plasma dump is located at the extreme end of the machine, and its power-density limit largely sets the size of the end vessel. In this case, we limit the plasma power density at the dump to $250 \mathrm{~W} / \mathrm{cm}^{2}$. This dump, like all those in the TDF, is water-cooled. The plasma startup quns are housed behind movable shielding at the end wall, and they inject a low-energy plasme along the field lines during startup.

The TDF is designed for maximum contact maintenance. 5pecialized tooling is provided for scheduled maintenance tasks, and general-purpose tooling is used for random failure repair. Therefore, contact operations can be performed in the vault during regular work schedules after a short cooldown with the magnets de-energized and the tritium removed. In this way, all the major connections can be made and broken in a contact mode, but components s re removed with remote tooling because of the high flux of gamma rays from unshielded machine ports. Because the components are designed for reliability, most maintenance tasks can be performed in an efficient contact mode, we are confident that the TDF will be a high-availability device with a specified $50 \%$ in the last half of its 15-year life.

\section{TESTING FACILITIES}

The principal testing area is the wall of the central cell in the area between the central cell beam ducts (figs, 2 and 3). There is direct access to two full-diameter test zones between the solenoid magnets, each capable of accommudating a $1-m$ long test article. Access to the areas inside the coil houndaries are also conveniently avallable to smaller test specimens. The major test capability offered by TDF is the ability to test full-size prototype blanket modules to qualify them for use in experimental power reactors. With steady-state run lengths of $>100$ hours, experimental components can be brought to thermal and tritium breeding equilibrium, and energy extraction may be demonstrated.

The neutron flux in the TDF is not high enough for lifetime testing of fusion-reactor, first-wall, structural materials. However, there is ample space and flux to do lifetime tests on insulators and other components that would be exposed to lesser fluence in a power reactor. There is, of course, ample flux for verifying neutronics models used for fusion system design. The machine itself is an excellent engineering test of the integration of a fusion reactor design into a long-life, high-duty-cycle machine. It san provide data on material interactions, interactions between systems, tritium and fuel processing, remote maintenance, and system reliability. 


\title{
4. PROGRAMMATIC CONTRIBUTION
}

The Magnetic Fusion Program has a strang need for a device like TDF because ( 1 ) it provides a test bed to demonstrate the reliability of technology developed in both the confinement and D\&T Programs when integrated into a device operating in the reactor mode; (2) it provides a testing facility for reactor systems, such as magnets, blarkets, neutral beams, and tritium breeding, under conditions of high neutran flux, neutron activiation, and tritium contamination; and (3) it provides a reactor-level (14-MeV) neutron flux over a large area (several squere meters), making practical the in situ testing of a broad range of materials and subassemblies.

A TDF can be built with conservative physics and technology, which should help ensure successful testing and performance. In addition, because it is a relatively modest device, these jobs could be accomplished at a relatively low cost in a timely manner.

\section{REFERENCES}

/1/ FOWLER, T. K. and LOGAN, B. G., Lawrence Livermore National Labopatory Report UCID-19193 (1981).

i2) SIMONEN, T. C., et al., Lawrence Livermore National Laboratory Report UCRL-B3515 (1980).

13) BATZER, T. H., et al., Lawrence Livermore National Laboratory Report UCRL-51617 (1974).

\section{ACKNOWLEOGMENTS}

This paper presents just a brief overview of work that will be completely reported by all participants in a forthcoming LLNL publication. Work performed under the auspices of the U.S. Department of Energy by Lawrence Livermore National Laboratory under Contract No. W-7405-Eng-48.

\section{ISTS I.AIMIE.R}

\begin{abstract}
Thin dicumeti wa prepered av an account of woth spotsored by an agenc) of the linited Sitates lioterament. Netither the I nited Staten Goternment nor the I'nisersity of (aliforais oor any of their cmploy res, makes any narranty, expresh of implied. or aseumes an Ispal lisbility of respomibility for the as. surary. completemess, or evefolness of any information, apparatus, product, at procen disclowed. of represeats that its use would not infringe prinalily on ned rights, Ruference berein to any spetific commercial prodacts, process, or sen ice by trade aame, Iraderasak, manufacturer, or c therhise, does not aecssatily cunvitule or imply its enduryemeat, recommendation, ar favoring by the l'nited stales liveremem or the t"aiversity of Califorria. The tipus and opinions of aurhan expresced herein do not aecesserily state or reflect these of the l'nited sinto liovernment thercof, and sball not be used for advertising or produtt etdosermetil purposes.
\end{abstract}


Techmical Information Deparment - Lawrence Livermore Laboratory University of California - Livermore, California 94550

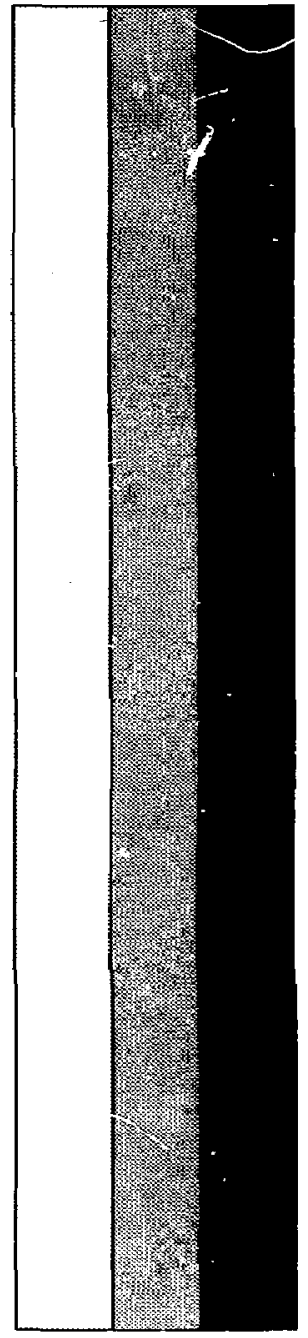

